\title{
Effects of Heating Rate on the Dynamic Tensile Mechanical Properties of Coal Sandstone during Thermal Treatment
}

\author{
Ming Li, ${ }^{1}$ Xianbiao Mao, ${ }^{1,2}$ Hai Pu, ${ }^{1}$ Yanlong Chen, ${ }^{1}$ Yu Wu, ${ }^{1}$ and Lianying $\mathrm{Zhang}^{3}$ \\ ${ }^{1}$ State Key Laboratory for Geomechanics and Deep Underground Engineering, China University of Mining and Technology, \\ Xuzhou, Jiangsu 221116, China \\ ${ }^{2}$ School of Mechanics and Civil Engineering, China University of Mining and Technology, Xuzhou, Jiangsu 221116, China \\ ${ }^{3}$ School of Civil Engineering, Xuzhou Institute of Technology, Xuzhou, Jiangsu 221018, China
}

Correspondence should be addressed to Xianbiao Mao; xbmaocumt@163.com

Received 25 June 2017; Accepted 18 September 2017; Published 18 October 2017

Academic Editor: Longjun Dong

Copyright (C) 2017 Ming Li et al. This is an open access article distributed under the Creative Commons Attribution License, which permits unrestricted use, distribution, and reproduction in any medium, provided the original work is properly cited.

\begin{abstract}
The effects of coal layered combustion and the heat injection rate on adjacent rock were examined in the process of underground coal gasification and coal-bed methane mining. Dynamic Brazilian disk tests were conducted on coal sandstone at $800^{\circ} \mathrm{C}$ and slow cooling from different heating rates by means of a Split Hopkinson Pressure Bar (SHPB) test system. It was discovered that thermal conditions had significant effects on the physical and mechanical properties of the sandstone including longitudinal wave velocity, density, and dynamic linear tensile strength; as the heating rates increased, the thermal expansion of the sandstone was enhanced and the damage degree increased. Compared with sandstone at ambient temperature, the fracture process of heat-treated sandstone was more complicated. After thermal treatment, the specimen had a large crack in the center and cracks on both sides caused by loading; the original cracks grew and mineral particle cracks, internal pore geometry, and other defects gradually appeared. With increasing heating rates, the microscopic fracture mode transformed from ductile fracture to subbrittle fracture. It was concluded that changes in the macroscopic mechanical properties of the sandstone were result from changes in the composition and microstructure.
\end{abstract}

\section{Introduction}

During underground coal gasification and coal-bed methane mining, the adjacent rock is exposed to two-sided conditions $[1,2]$ : impact loads (such as mechanical rock fragmentation, roof breaking, and rock bursts [3-5]) and high temperatures followed by cooling. However, due to different heating rates during coal combustion and the heat injection of the coal-bed methane, the macroscopic mechanical properties of jointed rock vary greatly from each other. In particular, when rock burst or large-area roof collapse occurs near the combustion zone, the impact load will seriously affect the stability of roadway surrounding rock, which is a serious challenge to the safe and efficient exploitation of resources. Therefore, in order to ensure the safe and efficient exploitation of resources, we must put forward the methods to control the stability of roadway surrounding rock through the use of effective monitoring technology [6] combined with scientific experiments and theoretical research $[7,8]$. The variational characteristics of mechanical properties and the damage mechanism are the crucial mechanical problems of coal and rock medium under the combined action of heat treatment and impact load.

When exploiting deep deposits, failure of the surrounding rock primarily depends on its tensile properties. During thermal treatment the physical properties of the rock change remarkably, which further alters its tensile mechanical properties [9-15]. Based on previous analyses and conclusions, it is known that heat plays an important role in the weakening of mechanical properties of rocks.

With recent advances in engineering, researchers have begun to study the influence of thermal treatments on rocks' dynamic mechanical properties. By testing the dynamic fracture toughness of gabbro and marble that had undergone heat treatments in high temperatures, Zhang et al. [16] discovered that the dynamic fracture toughness of both rocks increased in increments as the strain rate rose; however, they remained basically stable throughout heat treatment processes. Yin et al. [17] tested the dynamic fracture toughness of Laurentian 
granite during thermal treatments and established that the granite fracture toughness decreased rapidly with rising temperatures; their more recent study reported that the tensile strength of granite was enhanced by thermal treatment temperatures up to $100^{\circ} \mathrm{C}$ [18]. However, the tensile strength decreased quickly and the dynamic mechanical properties of the granite weakened significantly when the temperature rose above $100^{\circ} \mathrm{C}$. By conducting a dynamic Brazilian disk test with a SHPB system on Longyou sandstone after thermal treatments and analyzing the damage properties using CT scanning, scholars discovered a relationship between damage variables and loading strength; their studies concluded that the dynamic tensile strength of the rock increased as the loading rate and temperature decreased $[19,20]$. Further research results have shown that the dynamic tensile mechanical properties of rock are strongly dependent on temperature, and changes in mechanical properties are the result of varying temperatures that alter the rock's composition and microstructure [21-24].

Until now, studies on the mechanical properties of rocks have somewhat overlooked the influence of heating rate. Actually, the fundamental reason for different heating rates is not the temperature, but the heat injection rate and/or combustion speed during underground coal gasification and coal-bed methane mining. Furthermore, heat effect is the key factor in the influence of heating rate on the macroscopic mechanical properties of rock. Thirumalai and Demou [25] tested granite at different heating rates $\left(5^{\circ} \mathrm{C} / \mathrm{min}, 20^{\circ} \mathrm{C} / \mathrm{min}\right.$, and $50^{\circ} \mathrm{C} / \mathrm{min}$ ) in heat treatments of $20-400^{\circ} \mathrm{C}$ and found that, at the same temperatures, the effects of heat gradually increased as the heating rate increased. By heating gabbro to $300^{\circ} \mathrm{C}$ at heating rates of $5^{\circ} \mathrm{C} / \mathrm{min}$ and $1^{\circ} \mathrm{C} / \mathrm{min}$, Richter and Simmons [26] found that thermal expansion differed by 10 percent between the two heating rates, and the fracture characteristics of the sandstone were more remarkable at the faster heating rate. In metal material engineering, heating rate is the key factor in changing the mechanical properties of materials because it not only significantly affects crystal texture and recombination but also further influences the macroscopic mechanical properties [27-30]. From this perspective, because heating rate affects the crystal structure of rock, it inevitably changes its macromechanical properties as well.

Current studies focus on the impact of heating rates on the mechanical properties of rocks only as far as thermal expansion and thermal decomposition, while variations in their mechanical properties under different heating rates receive much less attention [31]. In order to provide valid theory support for the development of underground coal gasification and coal-bed methane mining, this paper conducted Brazilian disk tests on coal measure sandstone at $800^{\circ} \mathrm{C}$ temperature at different heating rates $(5,10,20,30,40$, and $50^{\circ} \mathrm{C} / \mathrm{min}$ ) and observed the subsequent slow cooling. Then, the material group and fine morphology of sandstone during heat treatments were measured by using X-ray diffraction and scanning electron microscopy (SEM), respectively. Finally, the change law of dynamic tensile characteristics of sandstone according to heating rates was investigated through both macro- and microapproaches.

\section{Experimental Setup and Methods}

2.1. Preparation of Specimens. Sandstone is the most common sedimentary rock and is the primary rock surrounding deep coal seams. Test samples were gathered from sandstone located at the top of a coal seam in a 1000-meter-deep working face at the Jiahe coal mine in Xuzhou, Jiangsu province of China. In its natural condition, the main ingredients of this sandstone include calcium feldspar (73\%), kaolinite (11.60\%), quartz $(10.48 \%)$, and microcline $(4.50 \%)$; the physical and strength properties are provided in Table 1. For this study, cylindrical rock specimens were acquired with a drilling machine and then cut to the appropriate lengths $(25 \mathrm{~mm}$ in length and $50 \mathrm{~mm}$ in diameter). The ends of the finished specimens were ground with a surface grinder to ensure flatness and parallelism at both ends at less than $0.05 \mathrm{~mm}$ and $0.02 \mathrm{~mm}$, respectively.

2.2. Testing Equipment. For this study, the specimens were heated with the MTS653 high-temperature furnace. The impact loading tests were performed on a $50 \mathrm{~mm}$ diameter SHPB setup, and the structure of SHPB system is shown in Figure 1. The SHPB apparatus consisted of a launching device, pressure bars, energy absorption device, signal acquisition system, and signal processing system. To measure the dynamic tensile characteristics of the sandstone, Brazilian disc tests were conducted with the specimens placed in the diameter direction between the incident bar and the cast bar.

2.3. Testing Methods. During the process of underground coal gasification, the burning temperature is maintained at about $800^{\circ} \mathrm{C}$, and it is known that heating rate makes a difference in the changes of the rock's mechanical properties when the heating rate is greater than $5^{\circ} \mathrm{C} / \mathrm{min}$ [32]. Therefore, in order to observe differences in the mechanical properties of the samples under different heating rates, the specimens were heated to $800^{\circ} \mathrm{C}$ at different heating rates $\left(5^{\circ} \mathrm{C} / \mathrm{min}\right.$, $10^{\circ} \mathrm{C} / \mathrm{min}, 20^{\circ} \mathrm{C} / \mathrm{min}, 30^{\circ} \mathrm{C} / \mathrm{min}, 40^{\circ} \mathrm{C} / \mathrm{min}$, and $50^{\circ} \mathrm{C} / \mathrm{min}$ ) and maintained at each temperature for $5 \mathrm{~min}$. Then, the specimen in furnace was cooled to room temperature at a slow rate to avoid thermal shock.

After the thermal treatment, dynamic tensile tests were carried out by using the SHPB test system at an impact load of $0.4 \mathrm{MPa}$. To test the dynamic characteristics of the sandstone samples more accurately, a T2 round copper sheet $(1 \mathrm{~mm}$ thick and $30 \mathrm{~mm}$ in diameter) was used to modulate impact load waves. The waveforms were shown in Figure 2, where it could be seen that the stress waves revealed prominently lateral vibration phenomenon during the wave propagation, and the specimens reached stress equilibrium before failure. This was checked by comparing the stress accounts at the two ends of the specimen $\left(\varepsilon_{i}+\varepsilon_{r} \approx \varepsilon_{t}\right)$ [33].

\section{Experimental Results and Analysis}

3.1. Physical Properties Analysis. Table 2 shows the longitudinal wave velocity $v$, density $\rho$, and thermal expansion coefficient $\alpha$ of sandstone under different heating rates at 


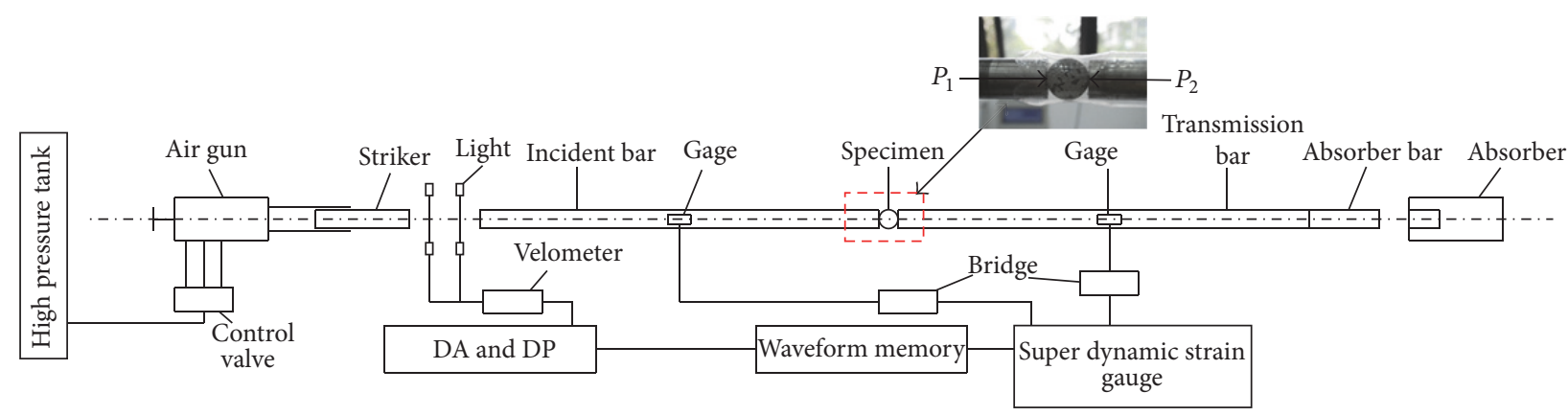

FIGURE 1: Split Hopkinson Pressure Bar (SHPB) system.

TABLE 1: Physical and strength properties of coal measure sandstone.

\begin{tabular}{lccccc}
\hline $\begin{array}{l}\text { Density } \\
\rho\left(\mathrm{g} / \mathrm{cm}^{3}\right)\end{array}$ & $\begin{array}{c}p \text {-velocity } \\
v(\mathrm{~km} / \mathrm{s})\end{array}$ & $\begin{array}{c}\text { Young's modulus } \\
E(\mathrm{GPa})\end{array}$ & $\begin{array}{c}\text { Poisson's ratio } \\
\mu\end{array}$ & $\begin{array}{c}\text { Tensile strength } \\
\sigma_{t}(\mathrm{MPa})\end{array}$ & $\begin{array}{c}\text { Compressive strength } \\
\sigma_{c}(\mathrm{MPa})\end{array}$ \\
\hline 2.45 & 2.50 & 6.36 & 0.25 & 3.62 & 74.65 \\
\hline
\end{tabular}

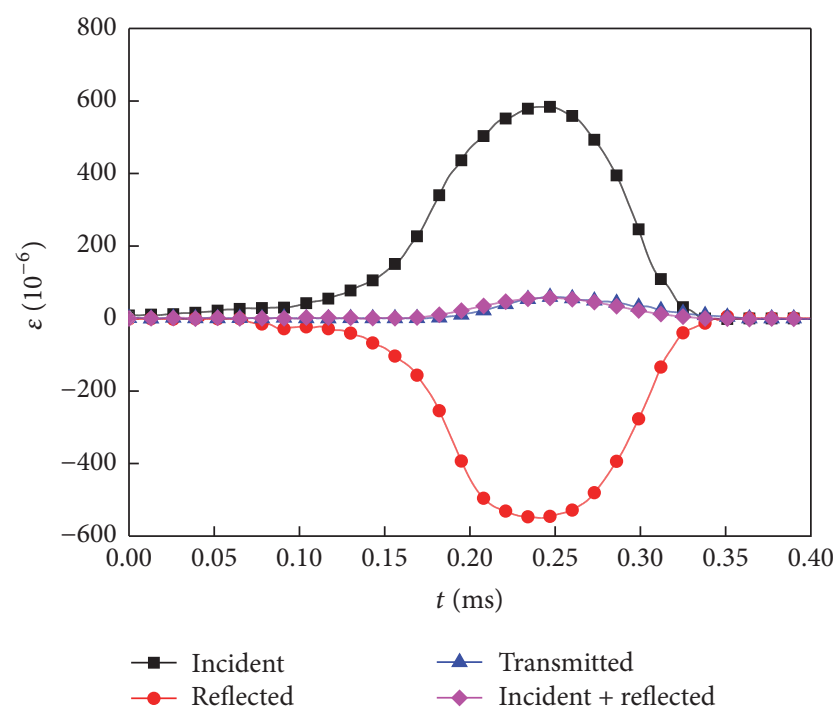

FIGURE 2: Strain balance check for a typical dynamic SHPB test with pulse shaping.

$800^{\circ} \mathrm{C}$; the corresponding curves are shown in Figure 3, where data in the table and figure are the averaged values of the sandstone's physical parameters.

In this paper, the thermal expansion coefficient was the coefficient of cubical expansion, that is, the rock volume change caused by an increase of $1^{\circ} \mathrm{C}$. It can be defined as follows:

$$
\alpha=\frac{\Delta V_{T}}{V_{T_{0}} \Delta T}=\frac{\left(V_{T}-V_{T_{0}}\right)}{V_{T_{0}}\left(T-T_{0}\right)}
$$

where $\Delta V$ is the thermal expansion volume; $T$ and $T_{0}$ are the insulating temperature and initial temperature of the specimen, which were $800^{\circ} \mathrm{C}$ and $25^{\circ} \mathrm{C}$, respectively; and $V_{T}$

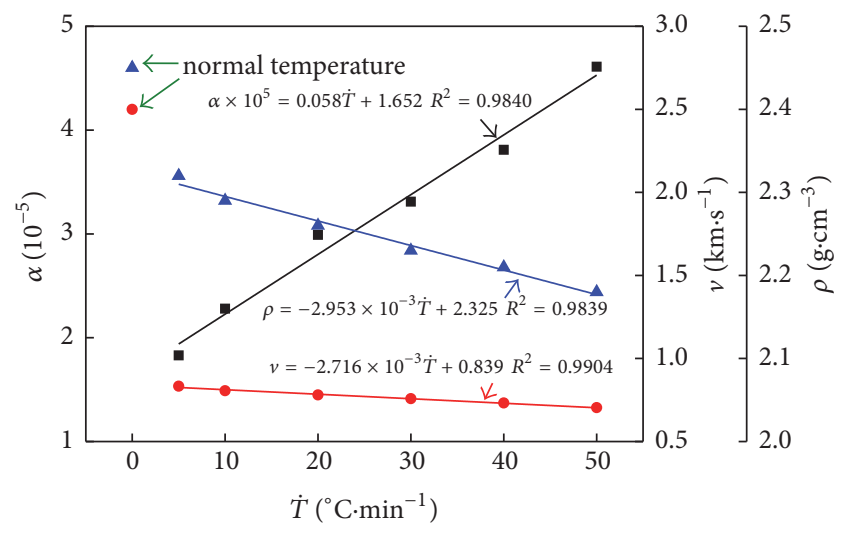

FIGURE 3: Relationship between physical parameters and heating rates. $v$ is the longitudinal wave velocity, $\rho$ is the density, and $\alpha$ is the thermal expansion coefficient.

and $V_{T 0}$ are the specimen volume corresponding to $T$ and $T_{0}$, respectively.

As shown in Figure 3, the longitudinal wave velocity and density of the sandstone specimens heat treated at $800^{\circ} \mathrm{C}$ were both lower than those at room temperature, with difference amplitudes of $66.68 \%-71.84 \%$ and $5.31 \%-11.02 \%$, respectively. Both the longitudinal wave velocity and the density decreased linearly with increasing heating rates. When the heating rate increased from $5^{\circ} \mathrm{C} / \mathrm{min}$ to $50^{\circ} \mathrm{C} / \mathrm{min}$, the longitudinal wave velocity decreased from $2.500 \mathrm{~km} / \mathrm{s}$ to $0.704 \mathrm{~km} / \mathrm{s}$, with an amplitude of $15.49 \%$; the density decreased from $2.32 \mathrm{~g} / \mathrm{cm}^{3}$ to $2.18 \mathrm{~g} / \mathrm{cm}^{3}$, with an amplitude of $6.02 \%$; and the thermal expansion coefficient increased linearly. At the same time, the thermal expansion coefficient increased from $1.83 \times 10^{-5}$ to $4.61 \times 10^{-5}$, which was an increase of 1.53 times.

3.2. Dynamic Tensile Mechanical Properties of Sandstone. According to the Brazilian disc (SNBD) test's computing 
TABLE 2: Physical parameters of sandstone under different heating rates.

\begin{tabular}{|c|c|c|c|c|c|c|c|}
\hline$\dot{T}\left({ }^{\circ} \mathrm{C} \cdot \mathrm{min}^{-1}\right)$ & $\begin{array}{c}0 \\
\text { (Normal temperature) }\end{array}$ & 5 & 10 & 20 & 30 & 40 & 50 \\
\hline$v(\mathrm{~km} / \mathrm{s})$ & 2.50 & 0.833 & 0.806 & 0.781 & 0.758 & 0.732 & 0.704 \\
\hline$\rho\left(\mathrm{g} / \mathrm{cm}^{3}\right)$ & 2.45 & 2.32 & 2.29 & 2.26 & 2.23 & 2.21 & 2.18 \\
\hline$\alpha\left(10^{-5}\right)$ & - & 1.83 & 2.28 & 2.99 & 3.31 & 3.81 & 4.61 \\
\hline
\end{tabular}

TABLE 3: Dynamic tensile strength of sandstone under different heating rates.

\begin{tabular}{|c|c|c|c|c|c|c|c|c|}
\hline$\dot{T}\left({ }^{\circ} \mathrm{C} \cdot \mathrm{min}^{-1}\right)$ & & $\begin{array}{c}0 \\
\text { (Normal temperature) }\end{array}$ & 5 & 10 & 20 & 30 & 40 & 50 \\
\hline \multirow{4}{*}{$\sigma_{\mathrm{dt}}(\mathrm{MPa})$} & Data 1 & 18.97 & 14.14 & 14.18 & 14.63 & 14.06 & 13.31 & 12.81 \\
\hline & Data 2 & 18.73 & 15.18 & 15.11 & 13.67 & 13.55 & 12.74 & 11.71 \\
\hline & Data 3 & 19.04 & 14.99 & 14.22 & 14.13 & 13.23 & 13.33 & 12.43 \\
\hline & Average & 18.91 & 14.77 & 14.50 & 14.14 & 13.61 & 13.13 & 12.32 \\
\hline
\end{tabular}

method for tensile stress, tensile strength can be obtained from the following formula:

$$
\sigma_{\mathrm{dt}}=\frac{P_{1}+P_{2}}{\pi D B}
$$

where $\sigma_{\mathrm{dt}}$ is the Brazilian dynamic tensile strength; $P_{1}$ and $P_{2}$ are the pressure on either side of the specimen (Figure 1); $D$ and $B$ are the diameter and thickness of the disc specimen, respectively.

The loading forces $P_{1}$ and $P_{2}$ on the two ends of the sample can be determined using the following formula:

$$
\begin{aligned}
& P_{1}=A E_{b}\left(\varepsilon_{i}+\varepsilon_{r}\right), \\
& P_{2}=A E_{b} \varepsilon_{t},
\end{aligned}
$$

where $A$ and $E_{b}$ are the cross-sectional area and elasticity modulus of the elastic bar, respectively; $\varepsilon$ is the strain caused by the stress wave in the elastic bar; and $i, r$, and $t$ are the incident wave, reflected wave, and transmitted wave, respectively.

As Figure 2 shows, the experimental process corresponded to the stress equilibrium assumption, so the following was obtained:

$$
\varepsilon_{i}+\varepsilon_{r}=\varepsilon_{t} .
$$

Then the following formula was acquired:

$$
P_{1}=P_{2}=A E_{b} \varepsilon_{t} .
$$

The tensile strength was obtained when (5) was plugged into (2). The tensile stress history was acquired by (2), and the slope of a straight line before peak stress was defined as the loading rate, as shown in Figure 4 [34]. Figure 5 shows that the dynamic tensile loading rate (at $0.4 \mathrm{MPa}$ ) of sandstone was about $152.6 \mathrm{GPa} / \mathrm{s}( \pm 0.5 \mathrm{GPa} / \mathrm{s})$ and remained the same at different heating rates.

The dynamic tensile strength of sandstone under different heating rates at $800^{\circ} \mathrm{C}$ can be acquired by (2) (5), as shown in Table 3, and the corresponding curve is shown in Figure 6.

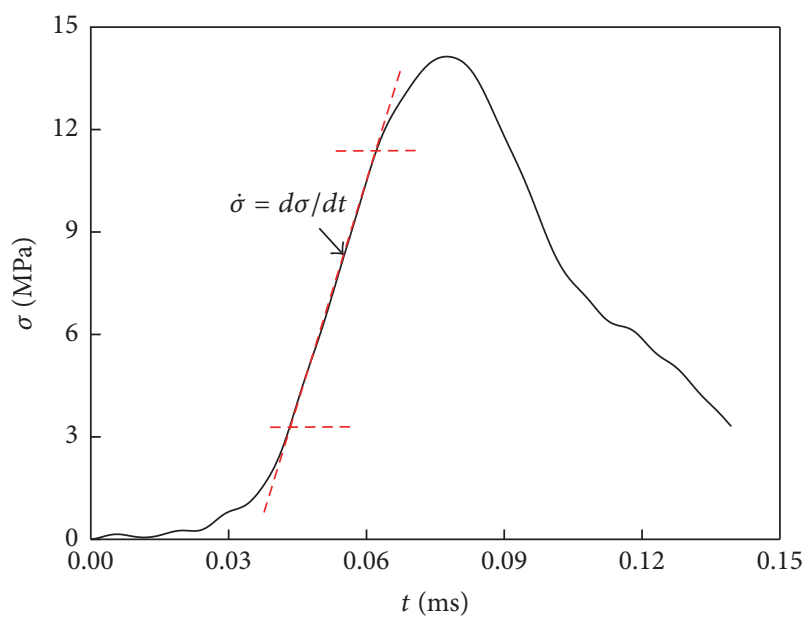

FIGURE 4: Calculation method of loading rate for the dynamic tensile test.

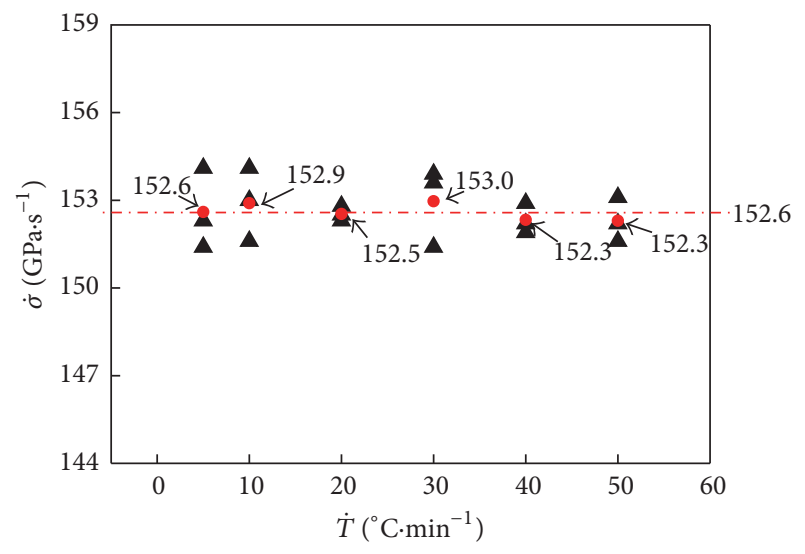

A Discrete value

- Average value

Figure 5: Tensile loading rates at different heating rate. 


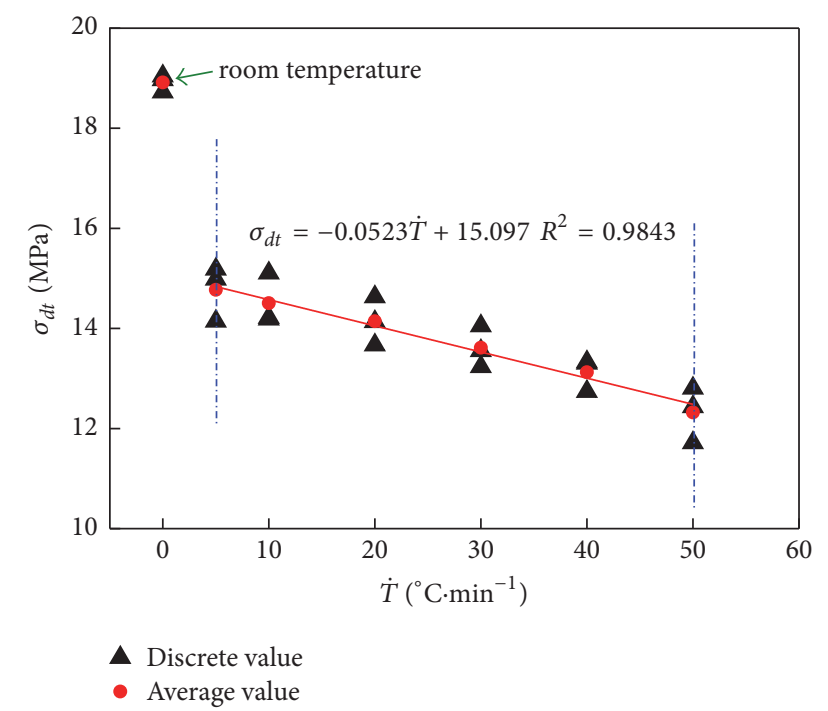

FIGURE 6: Variation of dynamic tensile strength with heating rates.

From Table 3 and Figure 6, the following information was then obtained.

(1) Compared with room temperature, the dynamic tensile strength was significantly lower (by about 21.89-34.84\%) under $800^{\circ} \mathrm{C}$ heating rates. Because the high temperature changed the main ingredients in the sandstone and the resultant warm molten caused flaws in the specimens, the specimens' dynamic tensile strength decreased markedly.

(2) As the figure shows, the dynamic tensile strength of the sandstone underwent significant changes under thermal treatments of different heating rates. Specifically, the dynamic tensile strength dropped linearly by $16.59 \%$ (from $14.77 \mathrm{MPa}$ to $12.32 \mathrm{MPa}$ ) with the heating rate increase of $5^{\circ} \mathrm{C} / \mathrm{min}$ to $50^{\circ} \mathrm{C} / \mathrm{min}$. The thermal stress difference between the inside and outside of the specimen increased when the heating rate increased, and, at the same time, the dynamic tensile strength of the sandstone decreased because the number of flaws inside the sandstone increased.

3.3. Macroscopic Failure Characteristics of Sandstone. The failure process and form of the test specimen were different between normal temperature and heat treatment temperatures, as shown in Figure 7. Under normal temperature, the specimen showed a primary crack in the centre, which expanded rapidly along the loading direction. The specimen was divided into two parts of equal size and then there were a number of small pieces in both sides of the loading due to local shear effect. After the high-temperature heat treatment, the specimen underwent three failure stages, as shown in Figure 8. First, there was a primary crack in the centre of the specimen along the loading direction. Second, both ends of the sample produced X-shaped cracks along the primary loading orientation from the continuation of the primary crack. Finally, the cracks intersected each other, causing macroscopic failure. When the specimen was broken into two pieces, there were many fine-grained chippings from shear and tension effects. There are many differences in the sandstone specimens' failure processes because the thermal evaporation and melt caused by the $800^{\circ} \mathrm{C}$ heat treatment created many flaws inside the specimens that weakened the local bearing capacity.

To prove the heating rate's influence on the specimen failures, the average grain diameter was analyzed after failure. First, the fragment was divided into eight groups using classifying screens measuring $0-2.5 \mathrm{~mm}, 2.5-5.0 \mathrm{~mm}, 5.0-8.0 \mathrm{~mm}$, $8.0-10.0 \mathrm{~mm}, 10.0-12.0 \mathrm{~mm}, 12.0-15.0 \mathrm{~mm}, 15.0-20.0 \mathrm{~mm}$, and $>20.0 \mathrm{~mm}$. Next, the proportion of every group fragment mass accounting for the total mass $W_{s n}$ was analyzed. Finally, the average grain diameter was obtained according to the following equation:

$$
r=\sum_{n=1}^{8} W_{s n} d_{v n}
$$

where $d_{v n}$ is the mean particle among every particle group, in other words, the average between the biggest particle and the smallest particle. Specifically, the smallest particle is $20.0 \mathrm{~mm}$ and the biggest is $50.0 \mathrm{~mm}$ when $n$ is eight.

Figure 9 shows the change rule of the fragmentation distribution parameter, which dropped linearly by $48.84 \%$ (from $23.61 \mathrm{~mm}$ to $12.08 \mathrm{~mm}$ ) as the heating rate rose from $5^{\circ} \mathrm{C} / \mathrm{min}$ to $50^{\circ} \mathrm{C} / \mathrm{min}$. From this, it was seen that the heating rate played a significant role in the dynamic tensile failure of the sandstone under the loading impact, and the failure gradually strengthened when the heating rate increased.

\section{Analysis of the Effects of Heating Rate on the Dynamic Tensile Mechanical Properties of Sandstone}

The mechanical properties of a material are closely related to its composition microstructure. To analyze the influence of heating rate on the mechanical properties of coal series sandstone, the material composition and microstructure morphology characteristics of sandstone subjected to different heating rates above $800^{\circ} \mathrm{C}$ were examined using a D8 Advance X-ray diffractometer and FEI Quanta TM 250 scanning electron microscope.

4.1. The Effects of Heating Rate on Sandstone Characteristics. Figure 10 shows a typical X-ray diffraction figure following $800^{\circ} \mathrm{C}$ heat treatment in which the material composition and content were acquired by Jude6.0. The rock quality percentages of key components are presented as Table 4, which lists the mean of three groups.

As can be seen in the table, from room temperature to $<800^{\circ} \mathrm{C}$ thermal treatment, feldspar was the key component of the sandstone (calcium feldspar accounted for the majority and microcline occupied a few parts) along with some quartzes. The biggest difference of the sandstone material composition before and after the heat treatment was the fact that the sandstone originally contained $11.60 \%$ kaolinite, which is a typical clay material and the main cementing material in sandstone; however, after the heat treatment, there was no kaolinite present [35]. It was concluded that 


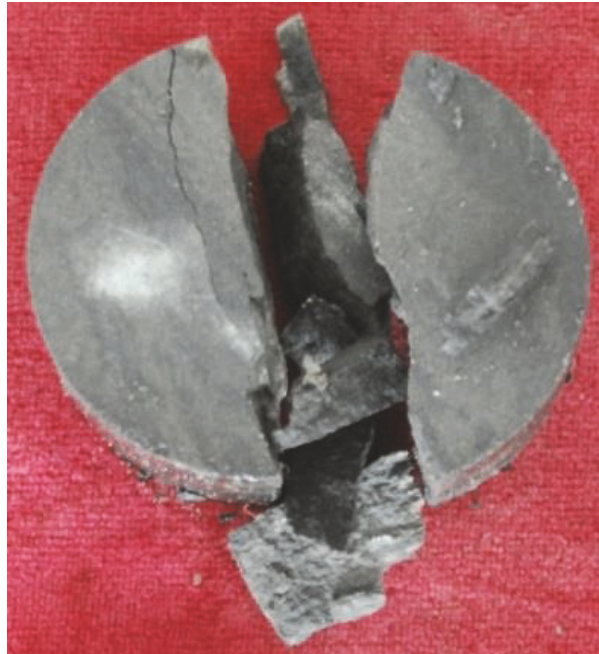

(a)

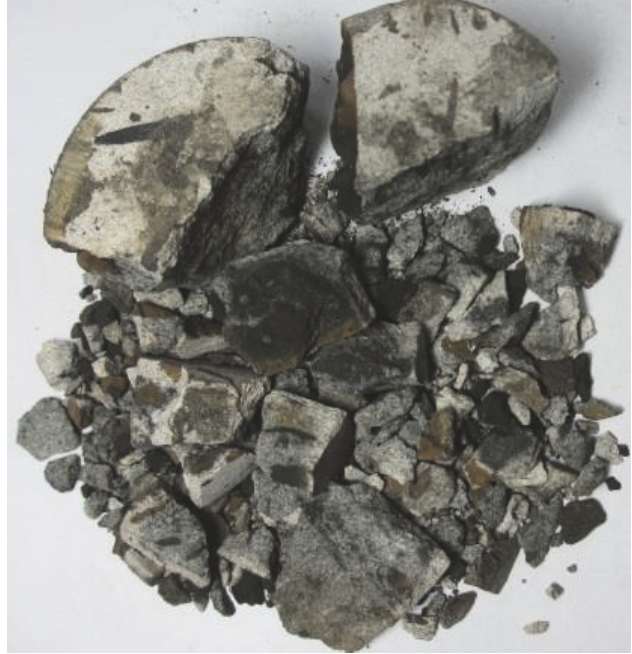

(b)

Figure 7: Dynamic Brazilian disc experiment specimen destruction: (a) normal temperature; (b) after $800^{\circ} \mathrm{C}$ heat treatment.

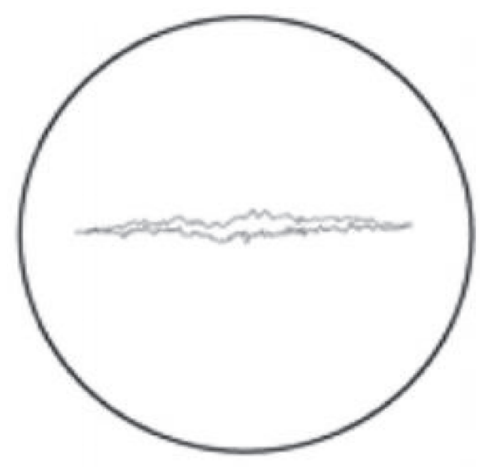

(a)

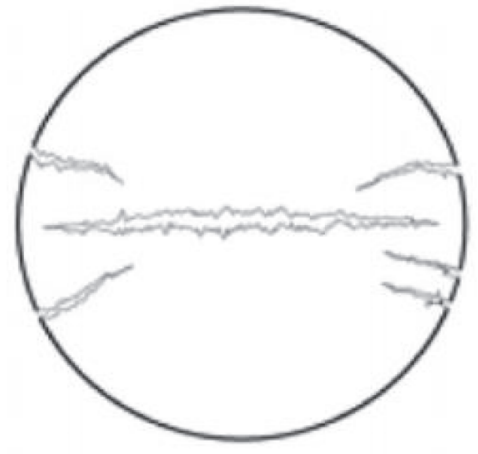

(b)

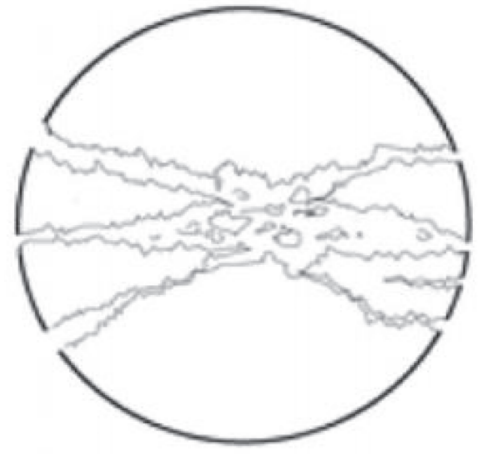

(c)

FIGURE 8: Schematics of failure model of specimen [15]: (a) initial cracks; (b) crack propagation; (c) crack transfixion.

the kaolinite underwent irreversible decomposition during the thermal treatment, which contributed to the significant decrease of dynamic tensile strength compared with that of sandstone at room temperature.

After the $800^{\circ} \mathrm{C}$ thermal treatment, the major components of the sandstone remained stable, and their contents were nearly the same when the heating rate was between $5^{\circ} \mathrm{C} / \mathrm{min}$ and $30^{\circ} \mathrm{C} / \mathrm{min}$. However, when the heating rate rose further, $1.90 \%$ carbonated calcium was detected in the sandstone components. Moreover, microcline and calcium feldspar levels increased from 0.039 to 0.081 when the heating rate rose from $30^{\circ} \mathrm{C} / \mathrm{min}$ to $40^{\circ} \mathrm{C} / \mathrm{min}$, and, at $50^{\circ} \mathrm{C} / \mathrm{min}$ heating rate, the two components increased to 0.49 . The content of quartz also increased significantly.

The analysis of the molecular structure revealed that the molecular interaction between the grains was attractive. Furthermore, the force between the molecules remained balanced at room temperature; however, under high temperature and high heating rates, the energy input was larger at unit time and there was a certain stress difference between the molecules, which was significant enough to change the chemical structure. Dawe et al. [36] discovered that, under high temperature and high heating rates, calcium feldspar underwent the following decomposition reaction:

$$
\mathrm{CaO} \cdot \mathrm{Al}_{2} \mathrm{O}_{3} \cdot 2 \mathrm{SiO}_{2} \longrightarrow \mathrm{CaO}+\mathrm{Al}_{2} \mathrm{O}_{3}+2 \mathrm{SiO}_{2}
$$

When the temperature gradually decreased, the $\mathrm{CaO}$ reacted with $\mathrm{CO}_{2}$ and $\mathrm{H}_{2} \mathrm{O}$ in the air, as shown in the following:

$$
\mathrm{CaO}+\mathrm{CO}_{2} \stackrel{\mathrm{H}_{2} \mathrm{O}}{\longrightarrow} \mathrm{CaCO}_{3}
$$

From that point, material decomposition reduced the mass fraction of anorthite and substance transformation improved that of the microcline. And $\mathrm{CaCO}_{3}$ was produced when the heating rate rose from $30^{\circ} \mathrm{C} / \mathrm{min}$ to $50^{\circ} \mathrm{C} / \mathrm{min}$.

Under high temperature, the calcium feldspar produced a certain amount of quartz. During the gradual cooling process, 
TABLE 4: Main components of sandstone.

\begin{tabular}{|c|c|c|c|c|c|c|c|}
\hline \multirow{2}{*}{$\begin{array}{l}\text { Substance } \\
\text { (chemical composition) }\end{array}$} & \multicolumn{7}{|c|}{ Heating rates $/\left({ }^{\circ} \mathrm{C} / \mathrm{min}\right)$} \\
\hline & Room temperature & 5 & 10 & 20 & 30 & 40 & 50 \\
\hline Quartz $\left(\mathrm{SiO}_{2}\right)(\%)$ & 10.80 & 4.00 & 4.20 & 3.20 & 1.80 & 11.50 & 7.50 \\
\hline Kaolinite $\left(\mathrm{Al}_{2} \mathrm{Si}_{2} \mathrm{O}_{5}(\mathrm{OH})_{4}\right)(\%)$ & 11.60 & 0 & 0 & 0 & 0 & 0 & 0 \\
\hline Microcline $\left(\mathrm{KAlSi}_{3} \mathrm{O}_{8}\right)(\%)$ & 4.50 & 2.70 & 5.10 & 3.30 & 3.70 & 6.50 & 29.70 \\
\hline Anorthite $\left(\mathrm{CaAl}_{2} \mathrm{Si}_{2} \mathrm{O}_{8}\right)(\%)$ & 73.00 & 93.30 & 90.70 & 93.50 & 94.50 & 80.10 & 60.90 \\
\hline Calcium carbonate $\left(\mathrm{CaCO}_{3}\right)(\%)$ & 0 & 0 & 0 & 0 & 0 & 1.90 & 1.90 \\
\hline
\end{tabular}

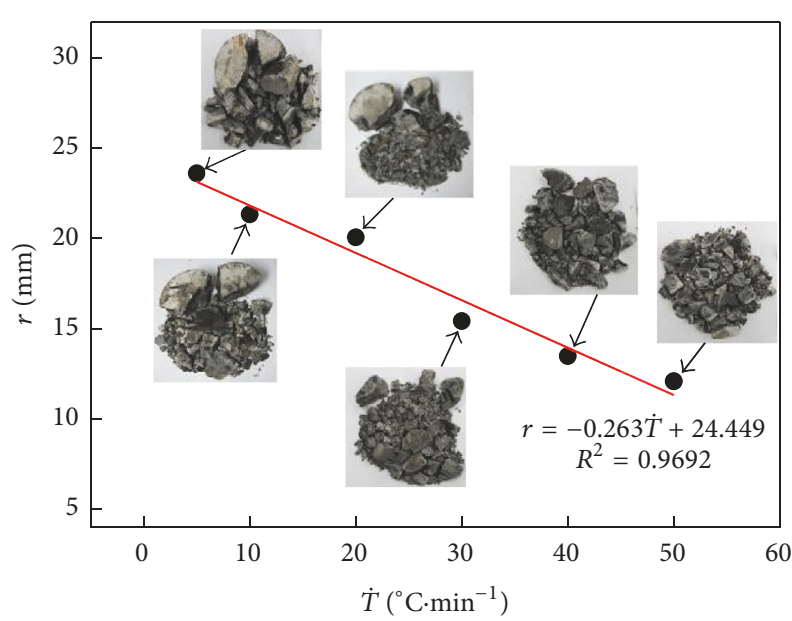

FIGURE 9: The change rule of fragmentation distribution parameter with heating rates. Figure 9 shows the change rule of the fragmentation distribution parameter, which is $\mathrm{dr}$.

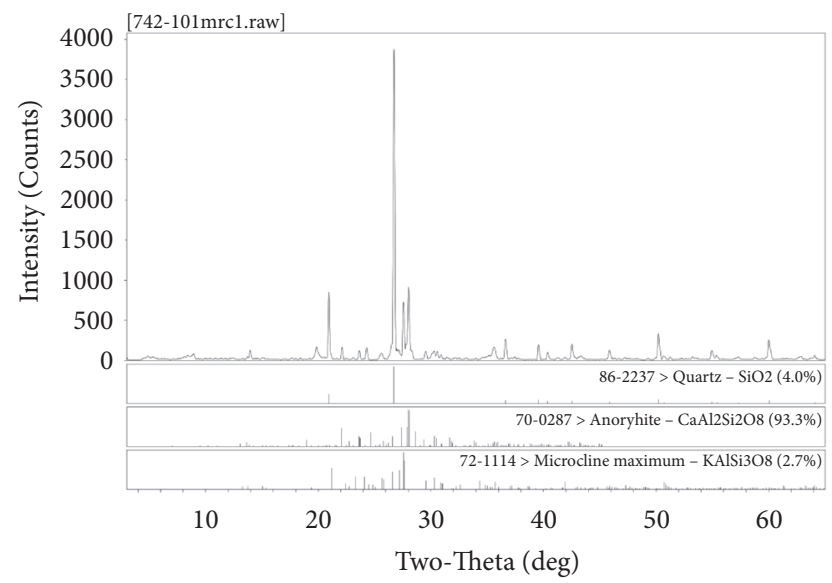

Figure 10: X-ray typical diffraction figure (86-2237 > Quartz-SiO2 (4.0\%): PDF the card number $>$ material composition-chemical formula (composition percentage)).

the calcium feldspar decomposed molten $\mathrm{Al}_{2} \mathrm{O}_{3}$ and $\mathrm{SiO}_{2}$, and potassium minerals crystallized to produce a certain amount of microcline, which increased the microcline in the sandstone. Although microcline and calcium feldspar were feldspathoid and contained the same crystal morphology, the material transformation resulted in changes to the macromechanical properties of the sandstone. Meanwhile, the dynamic tensile strength of the sandstone dropped significantly during the high heating rates because of the lubrication of the calcium carbonate.

\subsection{Effects of Heating Rate on Microscopic Features of Sandstone Failure}

4.2.1. Evolutional Characteristics in the Sandstone with Heating Rates. Figure 11 shows microscopic features in the sandstone during different heating rates at room temperature and thermal treatment $<800^{\circ} \mathrm{C}$, under which the profiles did not go through loading impact. From the figure, the following conclusions were drawn.

First, at room temperature, the interior of the sandstone was dense with some minor, connected cracks (Figure 11(a)). However, after the heating treatment, there were many cracks, holes, and other defects in the sandstone. The difference of microscopic features was one reason why the macromechanical properties of the sandstone were weakened.

Second, heating rate played a significant role in changing the microfeatures of the sandstone. Specifically, the cracks in the sandstone were relatively flat at the lower heating rate (Figures 11(b) and 11(c)). Holes and cracks in the sandstone incrementally increased at the heating rate of $20^{\circ} \mathrm{C} / \mathrm{min}$ (Figure $11(\mathrm{~d})$ ). At the heating rate of $30^{\circ} \mathrm{C} / \mathrm{min}$, structure defects in the sandstone were found in mineral volatility and thermal melting (Figure $11(\mathrm{e})$ ). At the heating rates of $40^{\circ} \mathrm{C} / \mathrm{min}$ and $50^{\circ} \mathrm{C} / \mathrm{min}$, network structure defects connected to microcracks in the sandstone (Figures 11(f) and 11(g)).

\subsubsection{Evolutional Rules of Morphology Features in Sandstone} Failure with Heating Rates. After the damage, morphology features in the sandstone were obtained by means of a scanning electron microscope, as shown in Figure 12. The following conclusions were drawn.

First, intensive dimples were observed in the sandstone fracture, which was an important morphology feature of a ductile fracture. Meanwhile, brittle transcrystalline fracture morphology represented by cleavage fractures and transcrystalline cracks existed in the sandstone fracture at the lower hating rate (Figure $12(\mathrm{a})$ ). At the heating rate of $20-30^{\circ} \mathrm{C} / \mathrm{min}$, there were two kinds of brittle fracture morphology (transcrystalline cracks and intergranular cracks) in the sandstone fracture after the impact tensile damage (Figure 12(b)). At the heating rates of $40-50^{\circ} \mathrm{C} / \mathrm{min}$, tearing ridges became the key 


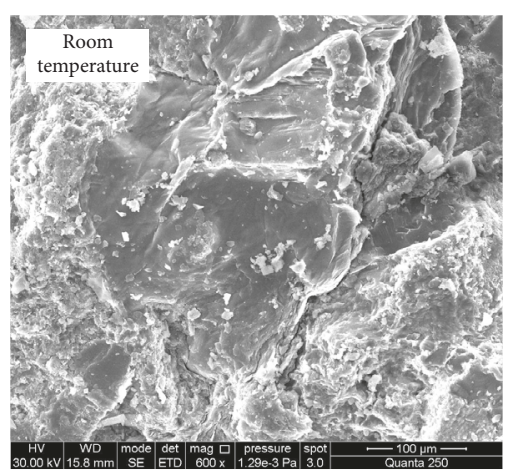

(a)

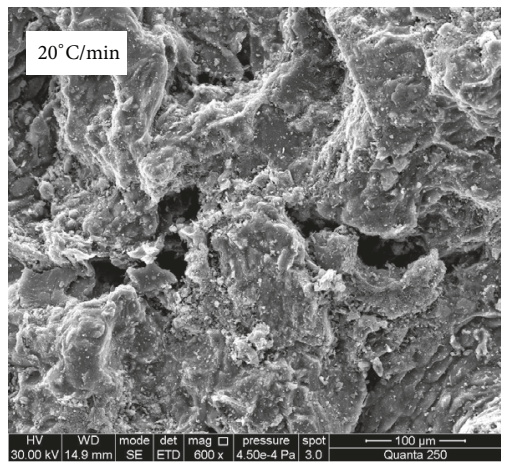

(d)

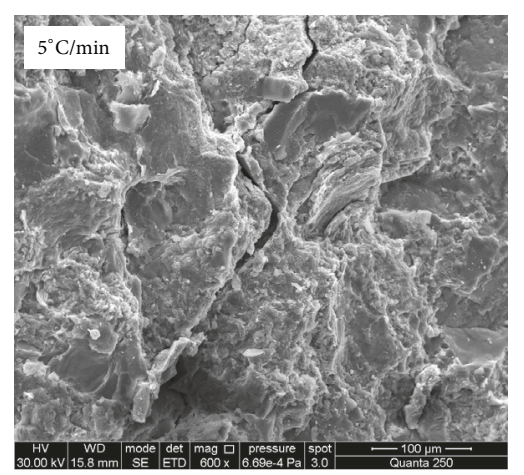

(b)

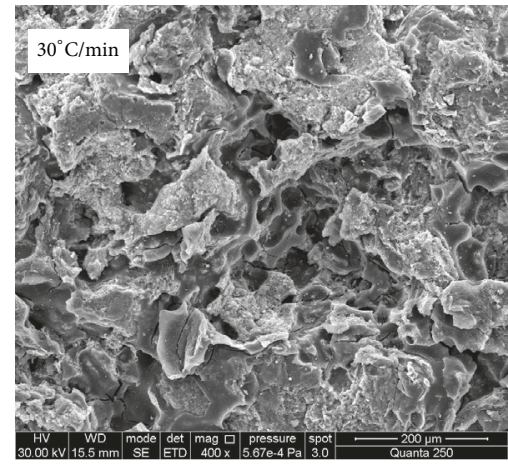

(e)

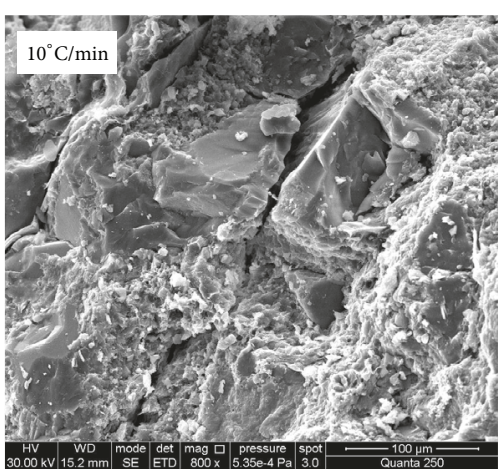

(c)

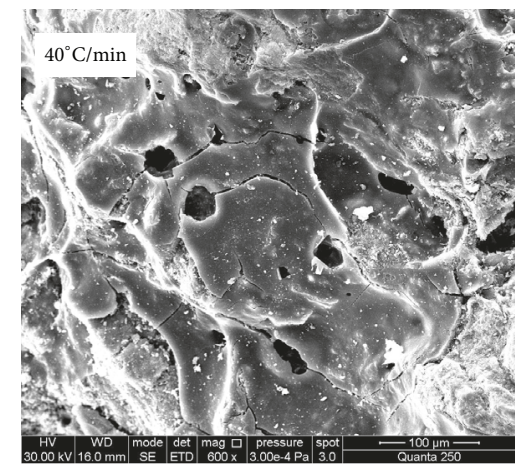

(f)

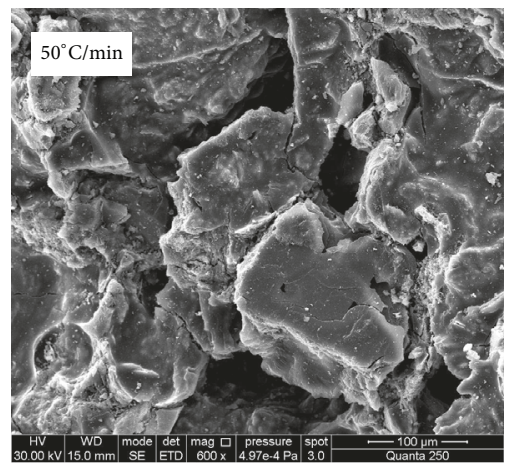

(g)

FIgURE 11: Microscopic features of the sandstone.

fracture morphology, and transcrystalline cracks occurred locally and propagated gradually (Figure 12(c)).

Second, from the fracture morphology in the sandstone at different heating rates, it was seen that the fracture mode transformed from ductile fracture to subbrittle fracture. Furthermore, from the endergonic angle, the following several fracture modes, arranged in order of size, were observed: dimple fractures, which were represented by ductile fractures, absorbed the most energy; transcrystalline fractures and quasicleavage fractures, embodied by transcrystalline cracks and tearing ridges, respectively, absorbed the second most energy; the brittle intergranular fractures representative of intergranular cracks absorbed the least.

Based on the evolution of the microfracture mode in the sandstone, the following conclusion was drawn: during loading impact, the energy dissipation of the sandstone's microfractures gradually decreased with increasing heating rate. However, the input energy and energy dissipation of the specimen were equal to each other under the same loading impact. Meanwhile, the decreasing microfracture energy made a significant difference in increasing the extent of macrodestruction, which explained why the sandstone's tensile fractures gradually increased as the heating rate increased.

\section{Conclusions}

Using a MTSMTS653 high-temperature furnace and Split Hopkinson Pressure Bar (SHPB) experimental system, this 

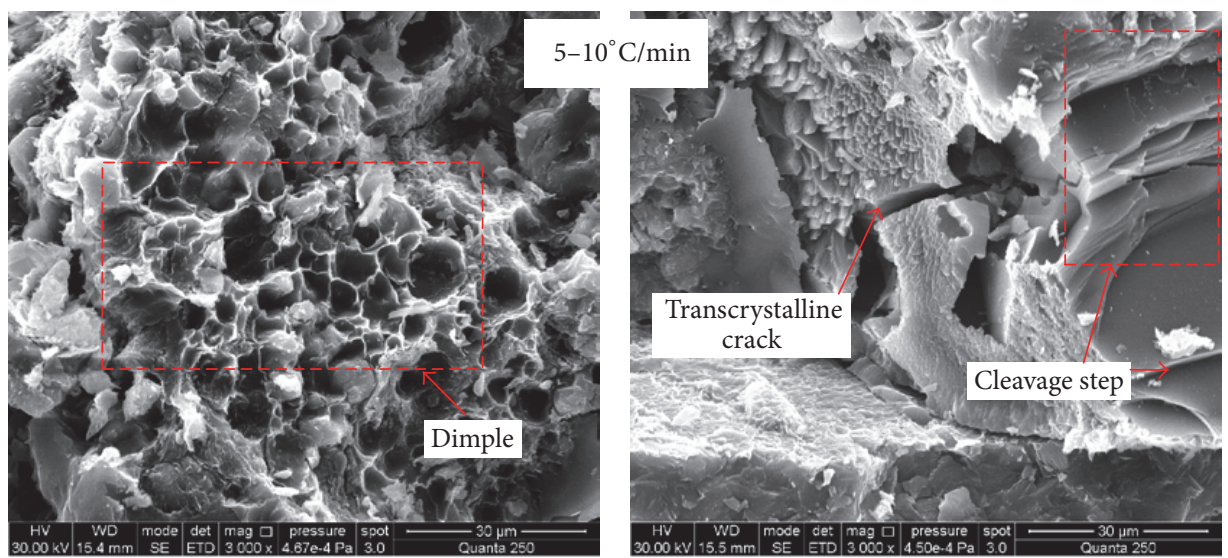

(a)

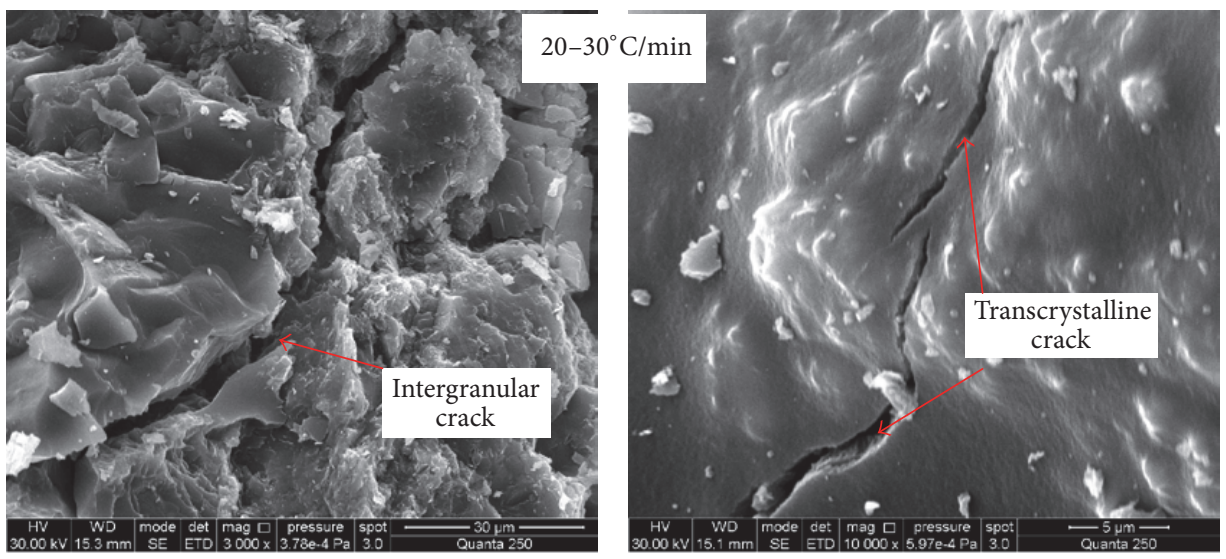

(b)

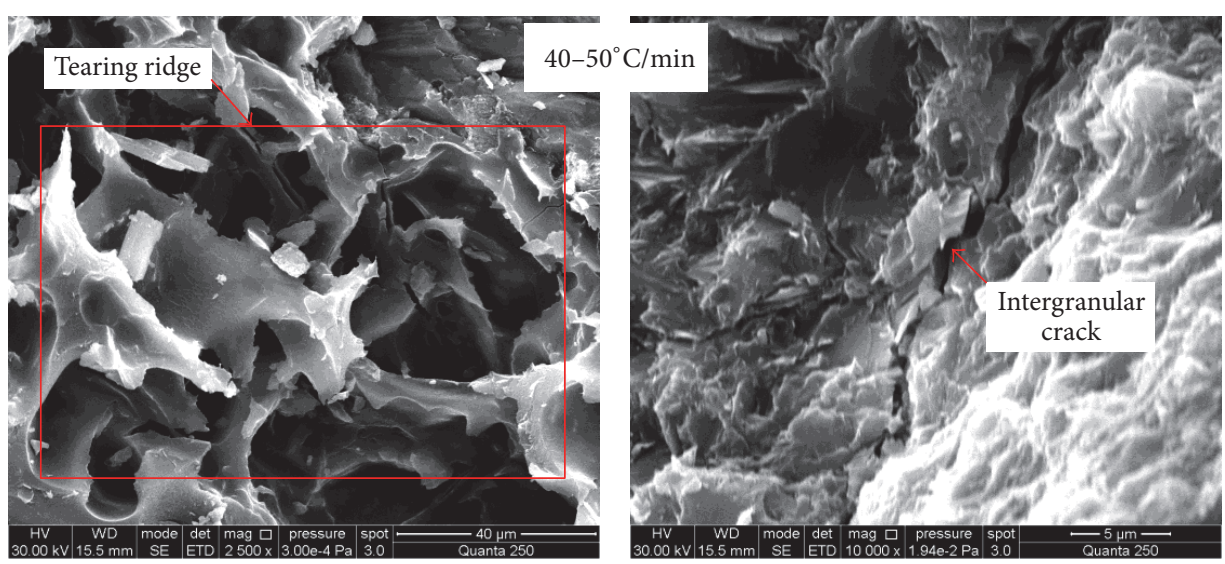

(c)

FIGURE 12: Microproperties of fracture morphology in the sandstone after loading impacts.

paper performed Brazilian disk tests on coal measure sandstone specimens at $800^{\circ} \mathrm{C}$ heat treatment and slow cooling from different heating rates. Additionally, the sandstone material composition and microstructure morphology characteristics of each specimen were assessed through X-ray diffraction and scanning electron microscopy (SEM) images. Based on the findings, the following conclusions were drawn.
Compared with those at room temperature, the longitudinal wave velocity, density, and dynamic tensile strength were less to different extents after heat treatments, while the physical mechanical geometrical factors dropped linearly with increasing heating rate. Additionally, the sandstone's thermal expansion ability was improved as the heating rate increased. 
In the dynamic Brazilian disc experiments, the specimens' macroscopic failures were caused by a center crack extending at normal temperature; however, the center cracks and cracks on both loading sides merged together and then ran throughout the specimen following the $800^{\circ} \mathrm{C}$ heat treatment. As such, the specimens' failure form was more complicated after heat treatment. As the heating rate increased, the average grain diameter decreased and the degree of specimen failure increased.

It was also discovered that kaolinite in the sandstone was decomposed by heat treatment, which was the main cause of weakness in the macroscopic mechanical properties. Moreover, the main causes of variations in the rocks' physical mechanical characteristics with heating rates were related to the changes of the composition proportion between anorthite, microcline, and calcium carbonate produced at a heating rate over $40^{\circ} \mathrm{C} / \mathrm{min}$.

Although the sandstone originally contained small cracks, the original cracks grew incrementally after thermal treatment, and mineral particles cracks, internal pore geometry, and other defects gradually appeared with increases in heating rates. The fracture mode transformed from ductile fracture to subbrittle fracture, and in the process, microscopic energy consumption of the sandstone gradually decreased, which contributed to the macroscopic damage.

\section{Conflicts of Interest}

The authors declare that they have no conflicts of interest.

\section{Acknowledgments}

Financial support for this work was provided by the Fundamental Research Funds for the Central Universities (2015XKZD06), the China Postdoctoral Science Foundation (2016M591960), and the National Natural Science Foundation (51674247, 51704281).

\section{References}

[1] L. Yang, X. Zhang, S. Liu, L. Yu, and W. Zhang, "Field test of large-scale hydrogen manufacturing from underground coal gasification (UCG)," International Journal of Hydrogen Energy, vol. 33, no. 4, pp. 1275-1285, 2008.

[2] A. Salmachi and M. Haghighi, "Feasibility study of thermally enhanced gas recovery of coal seam gas reservoirs using geothermal resources," Energy and Fuels, vol. 26, no. 8, pp. 5048-5059, 2012.

[3] Y. Tan, Y. Yin, S. Gu, and Z. Tian, "Multi-index monitoring and evaluation on rock burst in Yangcheng Mine," Shock and Vibration, vol. 2015, Article ID 624893, 5 pages, 2015.

[4] Z. Ouyang, Q. Qi, S. Zhao, B. Wu, and N. Zhang, "The mechanism and application of deep-hole precracking blasting on rockburst prevention," Shock and Vibration, vol. 2015, Article ID 625691, 7 pages, 2015.

[5] Y. Cheng, J. Bai, Y. Ma, J. Sun, Y. Liang, and F. Jiang, "Control mechanism of rock burst in the floor of roadway driven along next goaf in thick coal seam with large obliquity angle in deep well," Shock and Vibration, vol. 2015, Article ID 750807, 10 pages, 2015.

[6] L.-J. Dong, J. Wesseloo, Y. Potvin, and X.-B. Li, "Discriminant models of blasts and seismic events in mine seismology," International Journal of Rock Mechanics and Mining Sciences, vol. 86, pp. 282-291, 2016.

[7] L. Dong, J. Wesseloo, Y. Potvin, and X. Li, "Discrimination of mine seismic events and blasts using the fisher classifier, naive bayesian classifier and logistic regression," Rock Mechanics and Rock Engineering, vol. 49, no. 1, pp. 183-211, 2016.

[8] L. Dong, W. Shu, X. Li, G. Han, and W. Zou, “Three dimensional comprehensive analytical solutions for locating sources of sensor networks in unknown velocity mining system," IEEE Access, vol. 5, pp. 11337-11351, 2017.

[9] L. L. N. Mambou, J. Ndop, and J. M. B. Ndjaka, "Theoretical investigations of mechanical properties of sandstone rock specimen at high temperatures," Journal of Mining Science, vol. 50, no. 1, pp. 69-80, 2014.

[10] C. Inserra, S. Biwa, and Y. Chen, "Influence of thermal damage on linear and nonlinear acoustic properties of granite," International Journal of Rock Mechanics and Mining Sciences, vol. 62, pp. 96-104, 2013.

[11] K. Kim, J. Kemeny, and M. Nickerson, "Effect of rapid thermal cooling on mechanical rock properties," Rock Mechanics and Rock Engineering, vol. 47, no. 6, pp. 2005-2019, 2014.

[12] S. Ghabezloo and J. Sulem, "Stress dependent thermal pressurization of a fluid-saturated rock," Rock Mechanics and Rock Engineering, vol. 42, no. 1, pp. 1-24, 2009.

[13] H. Yavuz, S. Demirdag, and S. Caran, "Thermal effect on the physical properties of carbonate rocks," International Journal of Rock Mechanics and Mining Sciences, vol. 47, no. 1, pp. 94-103, 2010.

[14] F. Tang, L. Wang, Y. Lu, and X. Yang, "Thermophysical properties of coal measure strata under high temperature," Environmental Earth Sciences, vol. 73, no. 10, pp. 6009-6018, 2015.

[15] M. H. B. Nasseri, A. Schubnel, and R. P. Young, "Coupled evolutions of fracture toughness and elastic wave velocities at high crack density in thermally treated Westerly granite," International Journal of Rock Mechanics and Mining Sciences, vol. 44, no. 4, pp. 601-616, 2007.

[16] Z. X. Zhang, J. Yu, S. Q. Kou, and P.-A. Lindqvist, "Effects of high temperatures on dynamic rock fracture," International Journal of Rock Mechanics and Mining Sciences, vol. 38, no. 2, pp. 211225, 2001.

[17] T. Yin, X. Li, K. Xia, and S. Huang, "Effect of thermal treatment on the dynamic fracture toughness of laurentian granite," Rock Mechanics and Rock Engineering, vol. 45, no. 6, pp. 1087-1094, 2012.

[18] T. Yin, X. Li, W. Cao, and K. Xia, "Effects of thermal treatment on tensile strength of laurentian granite using brazilian test," Rock Mechanics and Rock Engineering, vol. 48, no. 6, pp. 22132223, 2015.

[19] W. Yao, Y. Xu, W. Wang, and P. Kanopolous, "Dependence of dynamic tensile strength of longyou sandstone on heattreatment temperature and loading rate," Rock Mechanics and Rock Engineering, vol. 49, no. 10, pp. 3899-3915, 2016.

[20] S. Huang and K. Xia, "Effect of heat-treatment on the dynamic compressive strength of Longyou sandstone," Engineering Geology, vol. 191, pp. 1-7, 2015. 
[21] Q. B. Zhang and J. Zhao, "A review of dynamic experimental techniques and mechanical behaviour of rock materials," Rock Mechanics and Rock Engineering, vol. 47, no. 4, pp. 1411-1478, 2014.

[22] S. Siegesmund, S. Mosch, C. Scheffzük, and D. I. Nikolayev, "The bowing potential of granitic rocks: rock fabrics, thermal properties and residual strain," Environmental Geology, vol. 55, no. 7, pp. 1437-1448, 2008.

[23] Y. Chen, T. Kobayashi, Y. Kuriki, and H. Kusuda, "Observation of microstructures in granite samples subjected to one cycle of heating and cooling," Journal of the Japan Society of Engineering Geology, vol. 49, no. 4, pp. 217-226, 2008.

[24] J. Zuo, H. Xie, H. Zhou, and S. Peng, "Thermal-mechanical coupled effect on fracture mechanism and plastic characteristics of sandstone," Science China Technological Sciences, vol. 50, no. 6, pp. 833-843, 2007.

[25] K. Thirumalai and S. G. Demou, "Effect of reduced pressure on thermal-expansion behavior of rocks and its significance to thermal fragmentation," Journal of Applied Physics, vol. 41, no. 13, pp. 5147-5151, 1970.

[26] D. Richter and G. Simmons, "Thermal expansion behavior of igneous rocks," in International Journal of Rock Mechanics and Mining Sciences \& Geomechanics Abstracts, vol. 11, pp. 403-411, Elsevier, 1974.

[27] M. M. Attallah, M. Strangwood, and C. L. Davis, "Influence of the heating rate on the initiation of primary recrystallization in a deformed Al-Mg alloy," Scripta Materialia, vol. 63, no. 4, pp. 371-374, 2010.

[28] E. Cruz-Zaragoza, P. R. González, J. Azorín, and C. Furetta, "Heating rate effect on thermoluminescence glow curves of LiF:Mg,Cu,P+PTFE phosphor," Applied Radiation and Isotopes, vol. 69, no. 10, pp. 1369-1373, 2011.

[29] W. Pan, Z. Ma, J. Liu, Q. Liu, and J. Wang, "Effect of heating rate on morphology and structure of $\mathrm{COFe}_{2} \mathrm{O}_{4}$ nanofibers," Materials Letters, vol. 65, no. 21-22, pp. 3269-3271, 2011.

[30] N. M. Lohan, B. Pricop, L.-G. Bujoreanu, and N. Cimpoeşu, "Heating rate effects on reverse martensitic transformation in a $\mathrm{Cu}-\mathrm{Zn}$-Al shape memory alloy," International Journal of Materials Research, vol. 102, no. 11, pp. 1345-1351, 2011.

[31] D. Wu, G. Liu, S. Chen, and R. Sun, "An experimental investigation on heating rate effect in the thermal behavior of perhydrous bituminous coal during pyrolysis," Journal of Thermal Analysis and Calorimetry, vol. 119, no. 3, pp. 2195-2203, 2015.

[32] C. Yong and C.-Y. Wang, "Thermally induced acoustic emission in westerly granite," Geophysical Research Letters, vol. 7, no. 12, pp. 1089-1092, 1980.

[33] Y. X. Zhou, K. Xia, X. B. Li et al., "Suggested methods for determining the dynamic strength parameters and mode-I fracture toughness of rock materials," International Journal of Rock Mechanics and Mining Sciences, vol. 49, pp. 105-112, 2012.

[34] F. Dai, R. Chen, and K. Xia, "A Semi-circular bend technique for determining dynamic fracture toughness," Experimental Mechanics, vol. 50, no. 6, pp. 783-791, 2010.

[35] G. J. Churchman, "Is the geological concept of clay minerals appropriate for soil science? A literature-based and philosophical analysis," Physics and Chemistry of the Earth, vol. 35, no. 1518, pp. 927-940, 2010.

[36] R. A. Dawe, G. C. Maitland, M. Rigby, and E. B. Smith, "High temperature viscosities and intermolecular forces of quasispherical molecules," Transactions of the Faraday Society, vol. 66, pp. 1955-1965, 1970. 


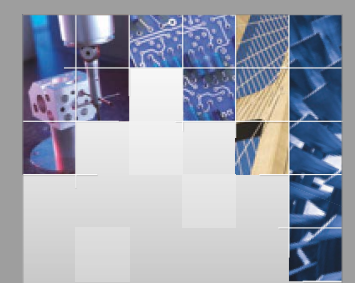

\section{Enfincering}
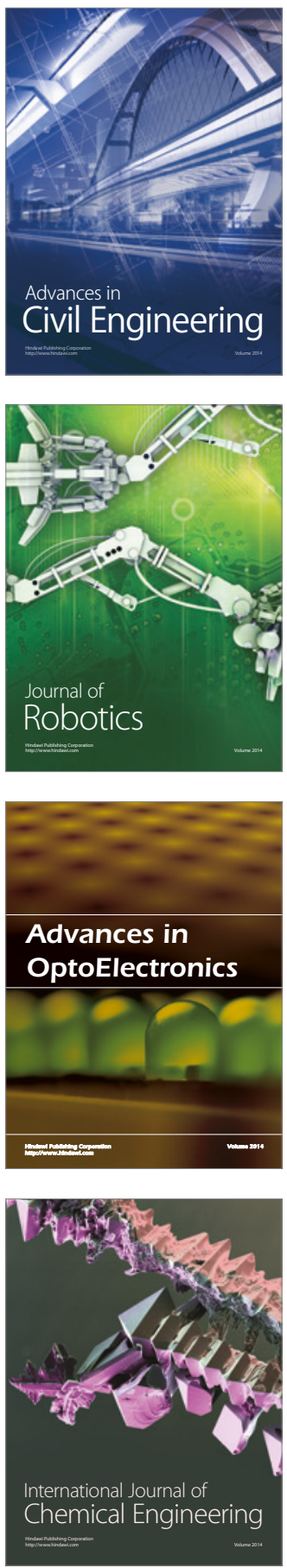

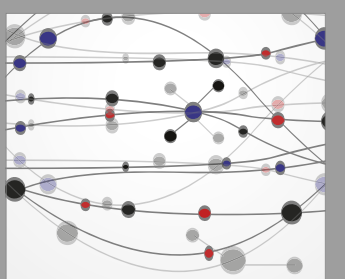

The Scientific World Journal

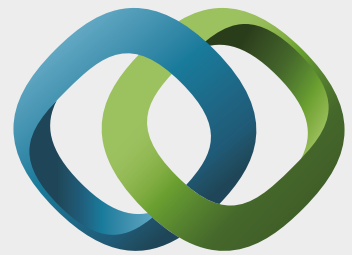

\section{Hindawi}

Submit your manuscripts at

https://www.hindawi.com
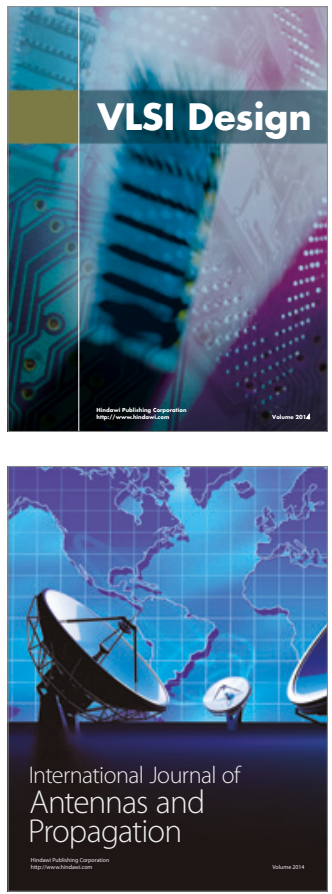

\section{Rotating}

Machinery
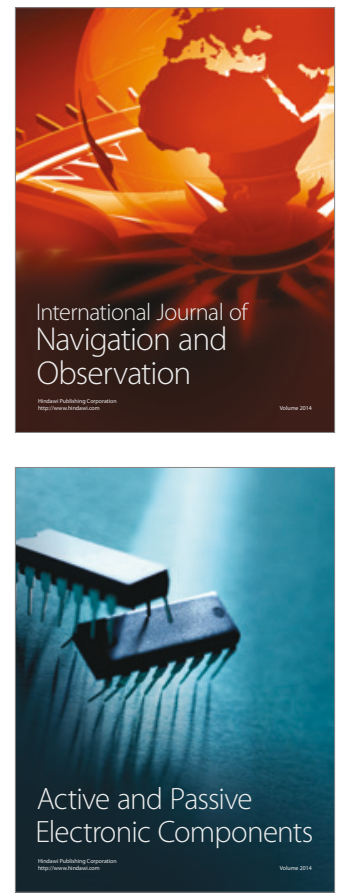
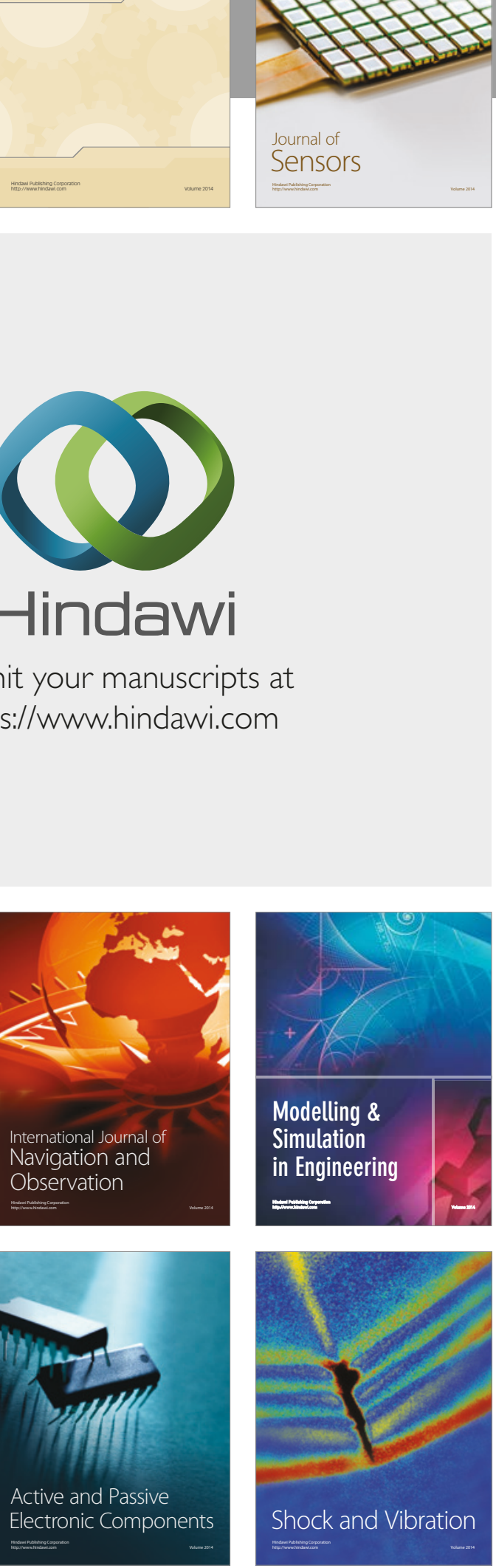
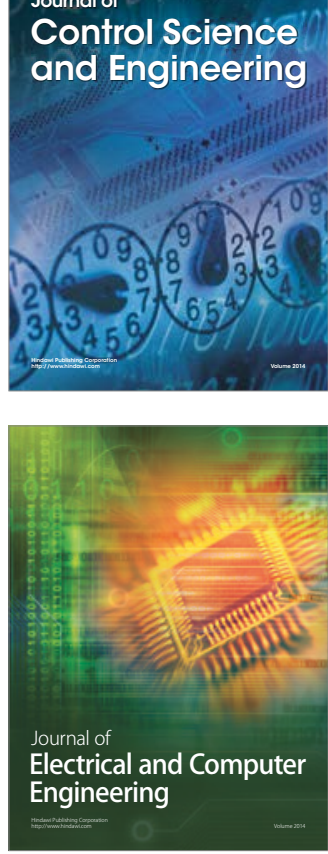

Distributed

Journal of

Control Science

and Engineering
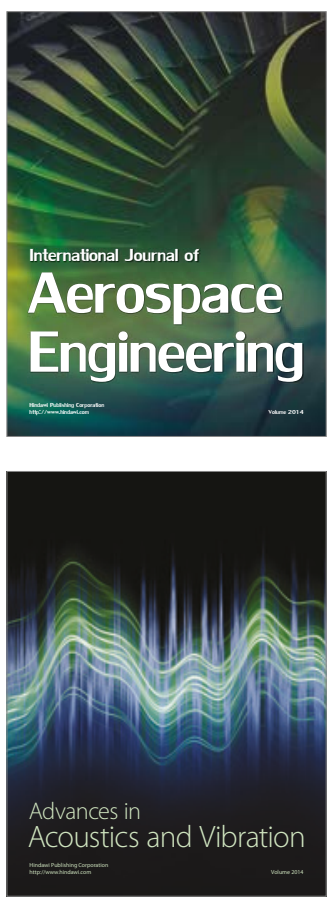

Sensor Networks 